\title{
DIGITAL TECHNOLOGY FOR CANCER PATIENTS
}

\author{
Szerző: \\ Anioke Blessing Nkiruka \\ Debreceni Egyetem
}

Szerző e-mail címe:

aniokenkiruka@gmail.com

\section{Lektorok:}

Fejes Zsolt (PhD)

Magyar Honvédség Egészségügyi Központ

Mező Ferenc (PhD)

Eszterházy Károly Egyetem

...és még két anonim lektor

\section{Absztrakt \\ DIGITÁLIS TECHNOLÓGLA A RÁKOS BETEGEKÉRT}

A rákbetegség olyan kóros sejtek szaporodásával járó élettani folyamat, amely során a sejtszaporodás folyamata szabályozatlanná és kontroll nélkülivé válik. A megbetegedett sejtek képesek a kiindulási helytől eltérő szervekben, szervrendszerekben is megjelenni, és adott esetben a beteg halálát okozni. Napjainkban számos, a digitális technológiát alkalmazó innovatív módszer létezik a rákbetegség kezelésére, követésére. Ide tartozik például a „pain buddy” applikáció, a különböző mobil egészségügyi alkalmazások, az intelligens piezoelektromos nyakláncok, az otthoni vérvizsgálatok különböző formái, az automatizált otthoni felügyeleti rendszerek vagy a különböző hordozható terápiás és fájdalomcsillapító eszközök. A technikai eszközök széleskörű elterjedését azonban különböző támogató és akadályozó tényezők is befolyásolják, melyek a cikkben ugyancsak összefoglalásra kerültek. A felsorolásra kerülő digitális technológiák biztonságosak, alkalmazásuk megkönnyítheti a rákbetegség kezelését, adott esetben kedvezőbb kimenetet eredményezve a beteg számára.

Kulcsszavak: digitális technológia, rákos betegek

Diszciplina: orvostudomány

\begin{abstract}
Cancer is a physiological progression in which the process of cell proliferation becomes unregulated and uncontrolled. Pathologic cells can also appear in organs and organ-systems other than the place of origin and can cause the death of the patient. There are many innovative ways and methods using digital technology to monitor and treat cancer. These include, for example, the 'pain buddy' application, various mobile healthcare applications, intelligent
\end{abstract}


piezoelectric necklaces, various forms of home blood tests, automated home monitoring systems, or various portable therapeutic and analgesic devices. Digital technology has perceived barriers and facilitators to digital technology to its adoption which are also summarized in the article. The digital technologies listed in the article are safe and can be used to facilitate the treatment of cancer resulting better outcome for the patient.

Keywords: digital technology, cancer patients

Disciplines: Medicine

Anioke Blessing Nkiruka (2020): Digital technology for cancer patients. Mesterséges intelligencia interdiszciplináris folyóirat II. évf. 2020/2. szám. 95-101. doi: 10.35406/MI.2020.2.95

In the age of digital, health can be embraced by health professionals, caregivers and individuals through the use of digital technology to offer strategies for the management of Cancer that are less-invasive and improved. Empowerment of cancer patients can be achieved by digital technology which has the ability to create innovative health care delivery models.

Cancer is a generic term for a large group of diseases that can affect any part of the body. Other terms used are malignant tumours and neoplasms. One defining feature of cancer is the rapid creation of abnormal cells that grow beyond their usual boundaries, and which can then invade adjoining parts of the body and spread to other organs, the latter process is referred to as metastasizing. Metastases are a major cause of death from cancer.

\section{Global Cancer Statistics}

In 2018, the $2^{\text {nd }}$ death leading cause worldwide which is responsible for about 9.6 million deaths is Cancer (Figure 1). Cancer is responsible for about 1 in 6 deaths globally (World Health Organization, 2018).

Figure 1: Global number of deathes by cause (2017). Source: (Max, 2020). Innovative Ways of Cancer Management Improvement through the Use of Digital Technology

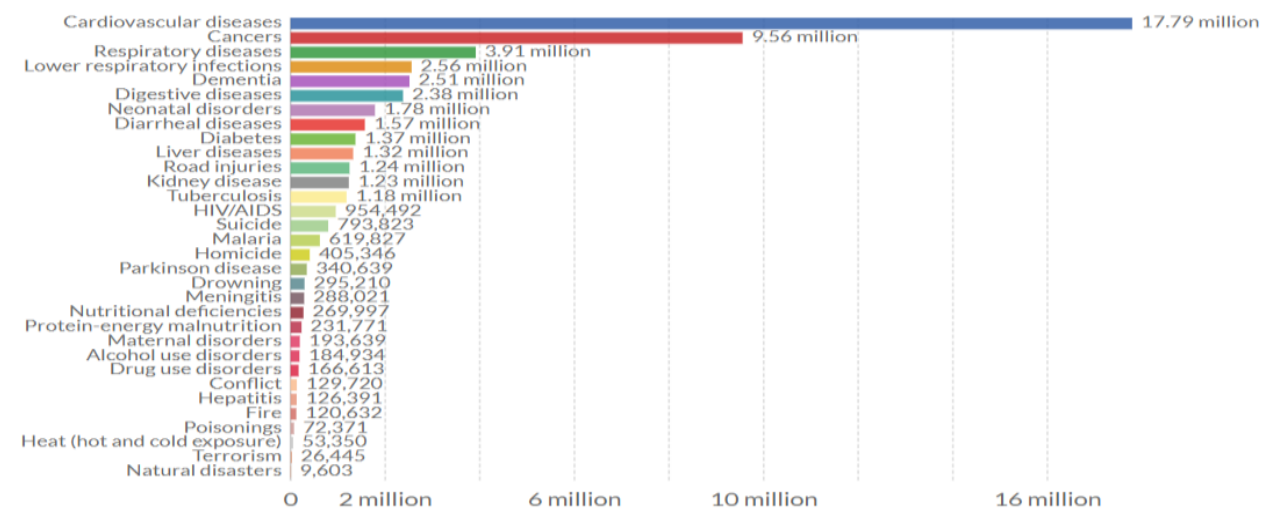


Nearly $70 \%$ of cancer deaths takes place in low- and moderate-income countries (World Health Organization, 2018).

5 top dietary and behavioral risks are responsible for $1 / 3$ of cancer risks. These includes low intake of vegetables and fruits, lack of physical exercise, use of tobacco, use of alcohol and high body mass index (World Health Organization, 2018).

The most significant factor for cancer is the Use of Tobacco which accounts for abouts $22 \%$ of deaths by cancer (World Health Organization, 2018).

In low- and moderate-income countries, one-fourth of cancer cases are due to Infections that are caused as a result of Cancer like Hepatitis and human papilloma virus (HPV) (World Health Organization, 2018).

Presentation at the Late-stage and lack of access to diagnosis and treatment are common. Only $26 \%$ of low-income countries in 2017 reported having public sector with available pathology services generally. The percentage ratio of treatment services reported for cancer between high-and-low income countries is 90:30 (World Health Organization, 2018).

Globally, it's estimated that Asia will see nearly half of the new cases and more than half of the cancer deaths in 2018, partly because the region has nearly 60 per cent of the world's population (United Nations, 2018). There is an increasing and vital impact of cancer economically. About 1.16 trillion Unites States dollars was the global estimated cost of cancer economically (World Health Organization, 2018).
Only 1 in 5 low- and moderate-income countries have the data required for cancer policy drive (World Health Organization, 2018).

Over 12,000 children are diagnosed with cancer every year in the United States. In addition to symptoms associated with their disease, children undergoing chemotherapy frequently experience significant pain, which is unfortunately often undertreated. The field of $\mathrm{m}$-Health offers an innovative avenue for pain assessment and intervention in the home setting (Fortier et. al., 2016).

According to the UN's International Agency for Research on Cancer (IARC) more than 18 million new cases of cancer were expected in 2108 and it was estimated that 9.6 million people died from various forms of the disease (United Nations, 2018).

Europe accounts for nearly a quarter of global cancer cases and one-fifth of cancer deaths, although it has only nine per cent of the global population (United Nations, 2018).

The Americas have more than 13 per cent of the global population but account for 21 per cent of cancers and some 14 per cent of global mortality (United Nations, 2018).

In Asia and in Africa, cancer deaths (57.3 per cent and 7.3 per cent respectively) are higher than the number identified (48.4 per cent and 5.8 per cent) (United Nations, 2018).

This is because these regions have a higher frequency of certain cancer types that are associated with poorer prognosis, and higher mortality rates, IARC says, in addition to limited access to diagnosis and treatment (United Nations, 2018). 
IARC reported that Lung cancer is a leading cause of death for both men and women and is the leading cause of cancer death in women in 28 countries (United Nations, 2018).

The highest incidence rates of this form of the disease in women are in North America, Northern and Western Europe - notably Denmark and the Netherlands - China, and Australia and New Zealand; with Hungary topping the list (United Nations, 2018).

\section{The Pain Buddy Application}

Promising tool for enhancing pain management, reducing symptoms and improving quality of life. An animated avatarbased tablet application was developed using state-of-the-art software. Key aspects of pain buddy include daily pain and symptom diaries completed by children. Remote monitoring of symptoms by uploading patient's data through internet to a cloud server. Cognitive and behavioural skills training. Iinteractive threedimensional avatars that guide children through the program. An incentive system to motivate engagement. (Fortier et al., 2016).

\section{Wearable-Based}

\section{Mobile Health Application}

It is used in Gastric Cancer Patients for automatic Postoperative Physical Activity Monitoring (walking steps) in inpatient stay. The wearable is Apple Watch for iOS and Samsung Gear S2 for Android. The wearable devices are able to send data to the customized apps in mobile phones. SQL: standard database language (Wu et al., 2019).

\section{Wearable health technology}

Fitness bands and similar devices are currently in the spotlight for their potential to encourage healthy behaviours that may reduce the risk of cancer. But they are also emerging as key players in the management of the disease. They contain sensors that enable people living with cancer to measure their heart rate, blood pressure and body temperature, and also to track sleep patterns and activity levels. More sophisticated versions allow the oncology team to analyse this information in real time, and advise or intervene, as needed. University of California researchers demonstrated the technology at a White House event, in October last year. They said that the collected data could 'lead to better treatment decisions, better survival rates, and better understanding between physician and patient' (Tonarelli, 2017).

\section{Smart piezoelectric necklaces}

A non-invasive way to monitor patient adherence to treatment, which is crucial to successful outcomes. Among the many novel technologies in the pipeline is a smart necklace that a study in artificial intelligence in medicine has shown can accurately detect the swallowing of medications. The device uses a piezoelectric sensor, which converts the movements that occur in the neck during swallowing into electrical signals. These are transmitted to a smart phone app whose algorithms can recognise swallowing due to medications, vitamins, saliva, drinking or speaking (Tonarelli, 2017). 


\section{Implantable and ingestible sensors}

Some sensors can be implanted under the skin or ingested, allowing for the continuous and unobtrusive monitoring of key vital signs, like heart rate, or medication adherence for example. These sensors can also alert patients and caregivers if a problem is detected, increasing the likelihood of health problems being addressed, before they become so serious that medical treatment is required. (Tonarelli, 2017).

\section{Home blood tests}

This allows cancer patients to test their blood at home. It is of particular benefit to patients receiving chemotherapy. The device can measure body temperature, levels of white cells and haemoglobin from a drop of blood obtained with a finger-prick kit. The technology can be of particular benefit to patients receiving chemotherapy. These need a laboratory blood test before each treatment cycle. And if their white blood cell levels are too low, the chemotherapy is cancelled. Using $3 \mathrm{~g}$ technology, the results are then transmitted to the hospital enabling prompt intervention by the oncology team if the patient's health deteriorates (Tonarelli, 2017).

\section{Automated home-based monitoring System}

Cancer-related pain can also be addressed through interventions that combine remote monitoring with telecare management. Patients with different types of cancer- lungs, breast and stomach - who had pain, depression or both use this system. They used an automated home-based symptom monitoring system consisting of a web-based application or interactive voice-recorded phone calls. Additionally, they received scheduled telephone calls by a nurse. By the end of the study, which lasted 12 months, the patients had significant less pain and depression (Tonarelli, 2017).

\section{Wearable therapeutic devices}

Technology is opening up exciting new possibilities also in cancer treatment. Take, for example, the Optune system for patients with glioblastoma, a type of brain cancer. It is worn on the head and has four thin adhesive patches that deliver low-intensity electric fields to the brain that aim to stop cancer cells from dividing and growing. Patients can wear the device, as they go about their daily routine, while treatment is delivered in a non-invasive way for up to 18 hours a day (Tonarelli, 2017).

\section{Pain-relief neuro-technology}

This consists of a lightweight band that wraps around the upper calf. Called Quell, the device uses electricity to stimulate the nerves that carry neural pulses to the brain, and induce the latter to block pain signals around the body. The technology includes a smart phone app that allows patients to track sleep, physical activity and other health indicators. (Tonarelli, 2017). 
Perceived Barriers and Facilitators to Digital Technology Adoption

Perceived Barriers are:

- Ownership of device

- Perceived value and training among older users

- Device management which includes forced obsolescence, versions of software and upgrades

- Home broadband price

- Limited exposure/knowledge of eHealth (e.g. poor digital health literacy)

- Lack of necessary devices

- Problems with financing eHealth solutions

- Problems with financing eHealth solutions

- Cognition

- Security

- Motivation

- Accessibility

- Unsuited services, design does not fit users' needs

- Confidentiality

- Missing fit into organizational structures, incentives

- Added workload (Schreiweis, 2019).

Perceived Facilitators are:

- Ease of use

- Improves communication

- Motivation

- Integrated into care

- Involvement of all relevant stakeholders
- Involvement of all relevant stakeholders

- Availability of resources

- User-friendliness (Schreiweis, 2019).

\section{Conclusion}

Cancer management is made possible with digital technologies for better client outcome.

Safe and acceptable follow up of cancer can be delivered using modern digital technology. Although the systems of follow-up of cancer which uses modern digital technology requires adequate research using randomized trials with the same results to provide evidence on the safety, quality of life impact, acceptability and cost effectiveness can cluster and be presented to patients, policy maker and health professionals.

Digital health tools were mostly adopted for online health information

Addressing the barriers and stressing the facilitators to technology adoption will help improve compliance.

\section{References}

Fortier, M. A., Chung, W. W., Martinez, A., Gago-Masague, S. and Sender, L. (2016). Pain buddy: A novel use of $m$-health in the management of children's cancer pain. Computers in Biology and Medicine, 76, 202-

214. doi: 10.1016/j.compbiomed.2016. 07.012

Max, R., M. \& Ritchie, H. (2020). Cancer. Our World in Data. Retrieved from: https://ourworldindata.org/cancer

Schreiweis, B., Pobiruchin, M., Strotbaum, V., Suleder, J., Wiesner, M. \& Bergh B. (2019). 
Barriers and Facilitators to the Implementation of eHealth Services: Systematic Literature Analysis. Journal of medical Internet research, 21(11), e14197. doi: $\underline{10.2196 / 14197}$

Tonarelli, L. (2017). Innovative ways digital health can belp manage cancer. Retrieved from: https://www.philips.com/a$\mathrm{w} /$ about/news/archive/future-healthindex/articles/20170222-innovativeways-digital-health-can-help-managecancer.html

United Nations. (2018, September 12). Cancer is a growing global threat and prevention is key, UN study shows. Retrieved from: https://news.un.org/ en/story/2018/09/1019102

World Health Organization. (2018, September 12). Cancer. Retrieved from: https://www.who.int/news-room/factsheets/detail/cancer

Wu J. M., Ho T. W., Chang Y. T., Hsu C., Tsai C. J., Lai F., and Lin, M. T. (2019). Wearable-Based Mobile Health App in Gastric Cancer Patients for Postoperative Physical Activity Monitoring: Focus Group Study. JMIR mHealth and uHealth, 7. doi: $\underline{10.2196 / 11989}$ 